\title{
Persistent Hepatitis E Infection in a Patient with Tuberous Sclerosis Complex Treated with Everolimus: A Case Report
}

\author{
Wobke E. M. van Dijk · Menno A. M. H. Vergeer · Joop E. Arends
}

Received: January 19, 2017 / Published online: March 3, 2017

(C) The Author(s) 2017. This article is published with open access at Springerlink.com

\begin{abstract}
Introduction: The incidence of hepatitis E (HEV) genotype 3 is rising in developed countries. HEV infections are usually self-limiting, but can become chronic in immunocompromised patients. This might lead to rapid fibrosis development even resulting in cirrhosis. Chronic HEV is mainly described in patients after solid-organ or hematological transplantations. We present the first case of HEV infection in a patient with tuberous sclerosis complex (TSC) treated with everolimus, a mammalian target of rapamycin (mTOR) inhibitor.

Case: A 46-year-old male with TSC was referred to the infectious diseases department with an acute rise of liver enzymes during routine laboratory check-up. He was diagnosed with an acute HEV infection. His current treatment for TSC was everolimus. After awaiting a
\end{abstract}

Enhanced content To view enhanced content for this article go to http://www.medengine.com/Redeem/ 8197F060326C5FD5.

W. E. M. van Dijk · J. E. Arends ( $₫)$

Department of Internal Medicine and Infectious

Diseases, University Medical Center Utrecht,

Utrecht, The Netherlands

e-mail: j.e.arends@umcutrecht.nl

M. A. M. H. Vergeer

Department of Internal Medicine and

Endocrinology, University Medical Center Utrecht,

Utrecht, The Netherlands spontaneous clearance for 3 months, everolimus was discontinued. Hereafter, the infection was cleared within another 3 months.

Discussion: Due to a favorable side-effect profile, everolimus is gaining popularity as an immunosuppressive therapy. However, in vitro experiments suggest that inhibition of mTOR leads to a significant increase in HEV replication. Thus far, there have been no clinical reports of HEV infections in patients treated with everolimus.

Conclusion: Due to higher dosing of everolimus in TSC patients, they are more vulnerable to the development of chronic HEV infection. Periodic assessment of transaminases in these patients is advised.

Keywords: Chronic hepatitis E; Everolimus; Hepatitis E; mTOR-inhibitor; Tuberous sclerosis complex

\section{INTRODUCTION}

Hepatitis E virus (HEV) infections are among the most important causes of hepatitis worldwide. Genotypes (GT) 1 and 2 are endemic in developing countries and cause about 70,000 deaths per year [1]. However, HEV GT 3 and 4 are emerging in developed countries [2, 3]. HEV GT3 is usually transmitted through consumption of undercooked meat from infected animals, such as pork, deer and wild boar [4-6]. 
However, other routes like blood transfusion and vertical transmission have also been described [7-11]. HEV infection results in (a)symptomatic acute hepatitis which is usually self-limiting within 4-6 weeks [5]. Patients with an immunocompromised status due to solid-organ or hematological transplantations are an exception [5]. In these groups of patients, HEV infection can develop into chronic HEV, which can cause rapid progression of liver fibrosis and cirrhosis [12,13]. A new group of immunocompromised patients at risk for HEV infection are those treated with monoclonal antibodies like rituximab and tocilizumab [14] or non-transplant patients treated with immunosuppressive drugs, like cyclosporine A and everolimus [15]. Everolimus is, among other things, used to treat malignant disease in tuberous sclerosis complex (TSC). It is a mammalian target of rapamycin (mTOR) inhibitor and suppresses immunity by several mechanisms, one of which is blocking $\mathrm{T}$ cell activation by cytokines. Here, we describe an HEV infection in a patient with tuberous sclerosis complex (TSC) who was treated with everolimus. All procedures followed were in accordance with the ethical standards of the responsible committee on human experimentation (institutional and national) and with the Helsinki Declaration of 1964, as revised in 2013. Informed consent was obtained from the court-appointed mentor.

\section{CASE}

A 46-year-old male was referred to the infectious diseases department with an acute rise of liver enzymes during routine laboratory evaluation (Table 1). His past medical history revealed tuberous sclerosis complex, for which he was treated with sirolimus since 2007 due to the progression of subependymal giant cell astrocytoma and multiple renal angiomyolipomas. This was switched to everolimus (10 $\mathrm{mg}$ per day) in 2013 after two registration studies had shown its safety and efficacy for these indications [16, 17]. At presentation (in 2015), the patient had suffered fatigue and weight loss of $5 \mathrm{~kg}$ during the preceding 3 months. There was no icterus, nausea or fever. A thorough food history was taken, but revealed no obvious route of transmission, such as the consumption of red meat, wild boar or deer. The patient did report consumption of well-cooked pork in the past. There was no history of blood transfusions. The patient had lived his entire life in a non-endemic country with good sanitary hygiene and there was no history of travelling abroad. Physical examination was normal and the liver was not palpable. An active HEV infection was diagnosed though serum polymerase-chain-reaction (PCR; nucleic acids were extraction with MP96 system; Roche Diagnostics, Germany; and primers and probes based on Zhao et al. [18]) with a cycle time of 23.41 cycles (amplification by a Taqman 7500 instrument; Applied Biosystems). After diagnosis, spontaneous clearance was awaited for a period of 3 months. However, since no spontaneous clearance occurred (PCR positive, cycle time 25.54), everolimus therapy was discontinued. Subsequent re-evaluation after another 3 months showed negative serum PCR and normalization of liver enzymes. Hereafter, everolimus therapy was restarted and no rise of liver enzymes was seen during more than 1 year follow-up (Fig. 1). During everolimus discontinuation, the patient had no complaints indicating progression of the giant cell astrocytoma. Additionally, computed tomography of the brain and kidneys following restart of everolimus therapy showed no progression of the brain tumor nor of renal angiomyolipomas.

\section{DISCUSSION}

This is the first report of chronic hepatitis $\mathrm{E}$ in a patient with tuberous sclerosis complex treated with the mTOR-inhibitor everolimus. Discontinuation of everolimus, after awaiting unsuccessful spontaneous clearance, resulted in the clearance of HEV and normalization of liver enzymes.

Due to its favorable side effect profile, everolimus is gaining popularity and is used as treatment for a variety of illnesses, such as malignancies, tuberous sclerosis complex and the Peutz-Jeghers syndrome, and after 
Table 1 Laboratory values

\begin{tabular}{lllll}
\hline $\begin{array}{l}\text { Laboratory test } \\
\text { (reference value) }\end{array}$ & Presentation & 3 months evaluation & $\begin{array}{l}\text { 6 months } \\
\text { evaluation } \\
\text { (viral clearance) }\end{array}$ & $\begin{array}{l}\text { 1 year } \\
\text { evaluation }\end{array}$ \\
\hline HEV RNA serum & $\begin{array}{l}\text { Positive (cycle number: } \\
24.30)\end{array}$ & $\begin{array}{c}\text { Positive (cycle number: } \\
25.54)\end{array}$ & Negative & NR \\
AST $(0-30 \mathrm{U} / \mathrm{L})$ & 430 & 137 & 25 & 36 \\
ALT $(0-35 \mathrm{U} / \mathrm{L})$ & 669 & 242 & 15 & 21 \\
Bilirubin $(3-21 \mu \mathrm{mol} / \mathrm{L})$ & 15 & 10 & 22 & 7 \\
ALP $(0-120 \mathrm{U} / \mathrm{L})$ & 267 & 147 & 77 & 102 \\
GGTP $(0-40 \mathrm{U} / \mathrm{L})$ & 243 & 145 & 24 & 20 \\
LD $(0-250 \mathrm{U} / \mathrm{L})$ & 450 & $\mathrm{NR}$ & 196 & 263 \\
Albumin $(35.0-50.0 \mathrm{~g} / \mathrm{L})$ & 42.0 & $\mathrm{NR}$ & $\mathrm{NR}$ & $\mathrm{NR}$ \\
Prothrombin time & 13.0 & $\mathrm{NR}$ & $\mathrm{NR}$ & $\mathrm{NR}$ \\
$\quad(11.8-14.8 \mathrm{~s})$ & & & & \\
\hline
\end{tabular}

mole micromole, $L$ liter, $U$ unit, $g$ gram, $A L P$ alkaline phosphatase, GGTP gamma-glutamyl transpeptidase, AST aspartate aminotransferase, $A L T$ alanine aminotransferase, $L D$ lactate dehydrogenase, $H E V$ hepatitis E virus, $N R$ not reported

a 6 months after restart everolimus

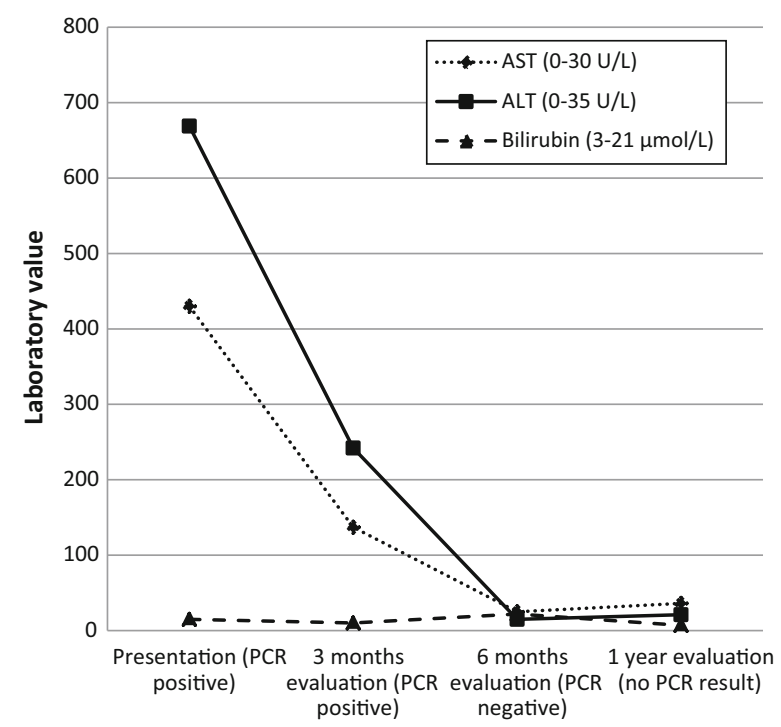

Fig. 1 Laboratory values during course of disease

solid-organ or hematological transplantation. Direct inhibition of mTOR and treatment with everolimus were found to stimulate HEV replication in human hepatoma cell lines in vitro [19]. A significant increase in $\mathrm{HEV}$ replication was seen after treatment with everolimus (dose $1 \mathrm{ng} / \mathrm{ml}$ ) and confirmed with doses of 10, 100 and $1000 \mathrm{ng} / \mathrm{ml}$. Everolimus doses used for tuberous sclerosis complex are 3-7 times higher than when used as immunosuppression after transplantation. The therapeutic range for everolimus in TSC used in our clinic is between 3 and $10 \mathrm{ng} /$ $\mathrm{ml}$. This might explain why higher doses of everolimus are a risk factor for hepatitis E development in these patients. No animal studies have been performed to assess the effect of everolimus on HEV replication, and patient studies have not yet identified everolimus as an influencing factor for HEV. Therefore, it should be considered that, apart from everolimus therapy, HEV persistence in this case might have been influenced by other factors, such as TSC-related or individual factors.

A similar stimulating effect on HEV replication in vitro has been found for cyclosporine $\mathrm{A}$ and tacrolimus, while mycophenolic acid has been shown to inhibit replication of HEV [20]. The latter was confirmed clinically in patients after heart transplantation, where mycophenolate mofetil was found to protect against chronic infections [21]. 


\section{CONCLUSION}

TSC patients receiving high-dose everolimus are vulnerable to the development of chronic HEV infection. Periodic assessment of transaminases in these patients is advised.

\section{ACKNOWLEDGEMENTS}

No funding or sponsorship was received for this study or publication of this article. All named authors meet the International Committee of Medical Journal Editors (ICMJE) criteria for authorship for this manuscript, take responsibility for the integrity of the work as a whole, and have given final approval for the version to be published. No editorial assistance was provided.

Disclosures. Wobke E. M. van Dijk, Menno A. M. H. Vergeer and Joop. E. Arends have nothing to disclose.

Compliance with Ethics Guidelines. All procedures followed were in accordance with the ethical standards of the responsible committee on human experimentation (institutional and national) and with the Helsinki Declaration of 1964, as revised in 2013. Informed consent was obtained from the court-appointed mentor.

Open Access. This article is distributed under the terms of the Creative Commons Attribution-NonCommercial 4.0 International License (http://creativecommons.org/licenses/ by-nc/4.0/), which permits any noncommercial use, distribution, and reproduction in any medium, provided you give appropriate credit to the original author(s) and the source, provide a link to the Creative Commons license, and indicate if changes were made.

\section{REFERENCES}

1. Rein DB, Stevens GA, Theaker J, Wittenborn JS, Wiersma ST. The global burden of hepatitis E virus genotypes 1 and 2 in 2005. Hepatology. 2012;55:988-97. Available from: http://www.ncbi. nlm.nih.gov/pubmed/22121109.

2. Arends JE, Ghisetti V, Irving W, Dalton HR, Izopet J, et al. Hepatitis E: an emerging infection in high income countries. J Clin Virol. 2014;59:81-8.

3. Okamoto H. Genetic variability and evolution of hepatitis E virus. Virus Res. 2007;127:216-28.

4. Dalton HR, Bendall R, Ijaz S, Banks M. Hepatitis E: an emerging infection in developed countries. Lancet Infect Dis. 2008;8:698-709.

5. Kamar N, Bendall R, Legrand-Abravanel F, Xia N-S, Ijaz S, et al. Hepatitis E. Lancet. 2012;379:2477-88.

6. Aggarwal R, Jameel S. Hepatitis E. Hepatology. 2011;54:2218-26. Available from: http://doi.wiley. com/10.1002/hep.24674.

7. Beale MA, Tettmar K, Szypulska R, Tedder RS, Ijaz S. Is there evidence of recent hepatitis $\mathrm{E}$ virus infection in English and North Welsh blood donors? Vox Sang. 2011;100:340-2. Available from: http://doi. wiley.com/10.1111/j.1423-0410.2010.01412.x.

8. Slot E, Hogema B, Riezebos-Brilman A, Kok T, Molier M, et al. Silent hepatitis E virus infection in Dutch blood donors, 2011 to 2012. Eurosurveillance. 2013;18:20550. Available from: http://www. eurosurveillance.org/ViewArticle.aspx?ArticleId=20 550 .

9. Xu C, Wang RY, Schechterly CA, Ge S, Shih JW, et al. An assessment of hepatitis E virus (HEV) in US blood donors and recipients: no detectable HEV RNA in 1939 donors tested and no evidence for HEV transmission to 362 prospectively followed recipients. Transfusion. 2013;53:2505-11. Available from: http://www.ncbi.nlm.nih.gov/pubmed/ 23829163.

10. Ranger-Rogez S, Alain S, Denis F. Virus des hépatites: transmission mère-enfant. Pathol Biol. 2002;50:568-75.

11. Siddiqui AR, Jooma RA, Smego RA. Nosocomial outbreak of hepatitis E infection in Pakistan with possible parenteral transmission. Clin Infect Dis. 2005;40:908-9. Available from: http://www.ncbi. nlm.nih.gov/pubmed/15736034.

12. Kamar N, Abravanel F, Selves J, Garrouste C, Esposito L, et al. Influence of immunosuppressive therapy on the natural history of genotype 3 hepatitis-e virus infection after organ transplantation. Transplantation. 2010;89:353-60. Available from: http://content.wkhealth.com/linkback/openurl?sid =WKPTLP:landingpage\&an=00007890-20100215000015. 
13. Kamar N, Garrouste C, Haagsma EB, Garrigue V, Pischke $S$, et al. Factors associated with chronic hepatitis in patients with hepatitis E virus infection who have received solid organ transplants. Gastroenterology. 2011;140:1481-9. Available from: http://www.sciencedirect.com/science/article/pii/ S0016508511002617.

14. Bauer H, Luxembourger C, Gottenberg J-E, Fournier $\mathrm{S}$, Abravanel F, et al. Outcome of hepatitis E virus infection in patients with inflammatory arthritides treated with immunosuppressants: a French retrospective multicenter study. Medicine (Baltimore). 2015;94:e675. Available from: http://www.ncbi. nlm.nih.gov/pubmed/25860212.

15. Höner $\mathrm{zu}$ Siederdissen C, Pischke S, Schlue J, Deterding K, Hellms T, et al. Chronic hepatitis E virus infection beyond transplantation or human immunodeficiency virus infection. Hepatology. 2014;60:1112-3. Available from: http://doi.wiley. com/10.1002/hep.26987.

16. Franz DN, Belousova E, Sparagana S, Bebin EM, Frost M, et al. Efficacy and safety of everolimus for subependymal giant cell astrocytomas associated with tuberous sclerosis complex (EXIST-1): a multicentre, randomised, placebo-controlled phase 3 trial. Lancet. 2013;381:125-32. Available from: http://www.ncbi.nlm.nih.gov/pubmed/23158522.

17. Bissler JJ, Kingswood JC, Radzikowska E, Zonnenberg BA, Frost $\mathrm{M}$, et al. Everolimus for angiomyolipoma associated with tuberous sclerosis complex or sporadic lymphangioleiomyomatosis (EXIST-2): a multicentre, randomised, double-blind, placebo-controlled trial. Lancet. 2013;381: 817-24. Available from: http://www.ncbi.nlm.nih.gov/ pubmed/23312829.

18. Zhao C, Li Z, Yan B, Harrison TJ, Guo X, et al. Comparison of real-time fluorescent RT-PCR and conventional RT-PCR for the detection of hepatitis $\mathrm{E}$ virus genotypes prevalent in China. J Med Virol. 2007;79:1966-73. Available from: http://www.ncbi. nlm.nih.gov/pubmed/17935186.

19. Zhou X, Wang Y, Metselaar HJ, Janssen HLA, Peppelenbosch MP, et al. Rapamycin and everolimus facilitate hepatitis $\mathrm{E}$ virus replication: revealing a basal defense mechanism of PI3K-PKB-mTOR pathway. J Hepatol. 2014;61:746-54. Available from: http://www.sciencedirect.com/science/ article/pii/S0168827814003730.

20. Wang Y, Zhou X, Debing Y, Chen K, Van Der Laan LJW, et al. Calcineurin inhibitors stimulate and mycophenolic acid inhibits replication of hepatitis E virus. Gastroenterology. 2014;146: 1775-83. Available from: http://www.ncbi.nlm.nih.gov/ pubmed/24582714.

21. Pischke S, Stiefel P, Franz B, Bremer B, Suneetha PV, et al. Chronic hepatitis $\mathrm{E}$ in heart transplant recipients. Am J Transplant. 2012;12:3128-33. Available from: http://doi.wiley.com/10.1111/j.1600-6143. 2012.04200.x. 